\title{
Televangelism in Sweden-Now? Is Channel 10 in Älmhult in Fact a Telechurch?
}

\author{
Jan-Åke Alvarsson
}

Ever since televangelism ${ }^{1}$ started in the United States, Sweden has been considered an impossible arena for that type of enterprise. At the time, almost all Swedes were formal members of the Swedish Lutheran Church, were heavily secularized, and were considered to be anti-Charismatic, and fairly anti-American in some regards. Unlike secularized American popular culture, which has generally been well received, Swedes have tended to be averse to the United States' international politics, or its expressions of "public" religiosity, like televangelism. Furthermore, up until that time, the state monopoly of Swedish radio and television had closely regulated the transmission of church services, and thus had impeded any such evangelization initiatives via TV.

Nevertheless, in 2005, when televangelism's heyday seemed to be over in the United States, a new Charismatic TV channel was founded in Älmhult in Småland, a place in the south that, prior to the channel's establishment, was known for only one thing; it was the birthplace and home to the head office of IKEA, the worldwide furniture company. The new channel was called "Channel 10" (Kanal 10). "Kanal" was a neutral designation witout any religious connotations and the number "10" was not

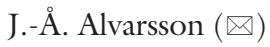

Department of Cultural Anthropology, Uppsala University, Sweden

(C) The Author(s) 2018

J. Moberg, J. Skjoldli (eds.), Charismatic Christianity in Finland, Norway, and Sweden, Palgrave Studies in New Religions and Alternative Spiritualities, https://doi.org/10.1007/978-3-319-69614-0_9 
used by any television channel in Sweden at the time. Since then, another, bigger channel, called TV10, has led to some confusion as to the identity of these two different channels.

In 10 years, Channel 10 has grown into a successful business whose principal product is Pentecostal or Charismatic preaching. ${ }^{2}$ The business idea is based on experiences from televangelism's heyday in the United States, in the 1980s. The present article initially asks the question: How can it be that televangelism attracts Swedes today, when it was considered impossible for it to do so only 30 years ago?

In the text, the actors behind the channel, its contents, and the reception of the programs are presented in light of contemporary changes taking place in the Pentecostal landscape, especially where these concern intergenerational conflicts of interest and ongoing mediatization. The material presented is discussed from a theoretical perspective on identity, inspired by Paul Ricoeur (2005), Erik Erikson (1964), and nostalgia as advocated by Clay Routledge et al. (2006, 2014).

The source material for this study is based on participant observation in Pentecostal churches, Pentecostal TV programs, interviews, websites, and academic works on Pentecostalism. The discussion also benefits from material gathered by the journalist Joakim Lundgren, who in 2013 carried out thorough research on Channel 10, commissioned by the Christian newspaper "The Day" (Dagen). ${ }^{3}$

\section{Pentecostalism in Sweden}

Pentecostalism reached Sweden as early as November 1906, through SwedishAmerican Andrew G. Johnson, who brought it over directly from 312 Azusa Street, the birthplace of international Pentecostalism in Los Angeles. In the beginning, it was an ecumenical movement, especially preponderant among Methodists and Baptists. After the initial outpouring of the Spirit in Skövde, Örebro was the center of activities for some time. In 1907, the focus gradually transferred to Gothenburg. Not until the 1910s did Stockholm start to play a part, always with Gothenburg as a questioning sceptic. ${ }^{4}$

In the late $1910 \mathrm{~s}$, the situation had changed considerably and a particular denomination, the Swedish "Pentecostal Movement" (Pingströrelsen; SPM) ${ }^{5}$ was founded in 1919. Through the firm leadership of Lewi Pethrus, the denomination united different pentecostalized groups and managed to become a leading movement on the Swedish, as well as on the European scene. In the 1980s, SPM's membership numbers surpassed 100,000 and it became the largest Free Church in Sweden. In 1937, the Baptist movement 
was divided into two denominations, the Örebro and the Stockholm Baptists, two branches that were well visible long before the split. The socalled "Örebro Mission" (Örebromissionen) became the second Pentecostal movement in Sweden, while the Stockholm Baptists turned more Evangelical and conservative. However, the Örebro Mission never managed to equal the Swedish Pentecostal Movement in its size or activities.

In 1962, a notable split occurred in the SPM when Maranata was founded by Norwegian Arne Imsen. The movement had initial success and lured back many old revivalists with its use of popular songs, "back to basics" preaching, renewed radicalism, and nostalgia for the "good old revival times." This heyday was short, however, and after a couple of years most of the enthusiasts had left the movement. In 1983, another notable Charismatic movement was born, Word of Life (Livets Ord) in Uppsala, led by Ulf Ekman, a former Lutheran priest who was heavily influenced by Neo-Pentecostals like Kenneth Hagin and Kenneth Copeland in the United States. The movement had great influence in Eastern Europe after the fall of the Iron Curtain, but its success in Sweden peaked at the turn of the century with some 3000 followers in the mother congregation in Uppsala and slightly more in a few scattered congregations in the rest of Sweden. In 1983 the Swedish Lutheran Church had its first Charismatic Movement in the Oasis Movement (Oasrörelsen). In due course, several other minor waves of Pentecostalism or Pentecostalized movements, like the Australian Hillsong Church, reached Sweden. Simultaneously, dividing lines between churches became blurred again, and people moved more freely between denominations (Moberg 2013, 187-188).

The arrival of these new waves of Pentecostalism also affected Classic Pentecostal churches. They changed their music style, introduced "worship music," often in English, and drew inspiration from concert culture, visible in their utilization of colorful lighting and, at times, smoke machines. Many churches were rebuilt to resemble concert halls and, while the centrality of the podium had previously reflected the importance of preaching in the service, the focus on the stage now emphasized the music as the main event, causing a generational divide and leaving a good number of the Classic Pentecostals alienated (cf. Moberg 2013, 106-107).

\section{The Situation of Swedish Radio and Television}

The Swedish radio broadcasting service was founded as a monopoly on March 21, 1924 under the name of "Radio Service Ltd" (AB Radiotjänst), hereafter referred to as 'Swedish Radio' (which from 1956 also broadcast 
television) and (after 1979 when television was separated and placed in a special foundation) 'Swedish Television', the more commonly used designations. ${ }^{6}$ The first program was broadcast on January 1,1925 ; incidentally this consisted of a church service from the Sankt Jacob Lutheran church in Stockholm. In 1956, the company started transmitting television programs six days a week, at first only for a few hours per night. The limited time given was seen as an opportunity to reach the public, used by the authorities to inform, educate, and enlighten the Swedes. The telecasting from this single channel was therefore censored and without commercials. It was considered to be "public service." In 1969, a second television channel was created: TV2. This addition was intended to give the illusion of variety, while the channel tried to meet the growing challenges from international media. Not until 1979, when the whole company was divided into four subsidiaries and reorganized, did Sweden see the first legal alternatives to this monopoly, in the form of community radio. As we shall see, Pentecostals felt immediately inspired to utilize that possibility. A major threat to Swedish national television appeared in December 1987, when the commercial channel TV3 started telecasting via satellite from London. Swedish authorities tried to stop the enterprise with legislation, but failed; in 1991 they capitulated and allowed a new Swedish commercial TV channel: TV4. Since then, commercial radio and TV channels have proliferated, but lip service is paid to the idea of "public service" broadcasting in that the fact that possession of a TV set is still subject to a quarterly fee.

\section{The Pentecostal Use of Media: The Swedish Background}

Classic Pentecostalism in Sweden reflects many of the traits found in international Pentecostalism: It started in 1906, it promotes a Charismatic spirituality, and it utilizes the latest media trends. ${ }^{7}$ In its earliest days in 1906, and for quite some time afterwards, newspapers and journals were used to inform and inspire its adherents. At Azusa Street in Los Angeles, the revival's journal was called The Apostolic Faith. In Sweden, Pentecostalism was welcomed and promoted by editor Richard Edelberg in his Örebro-based, Evangelical journals "The Närke Paper" (Nürkesbladet) ${ }^{8}$ and "The Swedish Tribune" (Svenska Tribunen). But for the impatient Pentecostals, these were not enough. Therefore, the first genuinely Pentecostal periodical, "Embers from the Altar" (Glöd frain altaret), was published in Gothenburg in 1909. When this journal was discontinued, another one took its place almost immediately in Stockholm in 1911: "The Voice of the Bridegroom" 
(Brudgummens röst). The editor-in-chief was Carl Hedeen and his co-editor was Olov Leonard Björk-both well-known figures in the early Pentecostal Movement. A young, up-and-coming preacher, the new pastor of the small Filadelfia Congregation in Stockholm, was invited to become an assistant editor. His name was Levi Petrus, soon to be changed to Lewi Pethrus. Among other contributions, he provided the journal with self-composed hymns. However, in the mid-1910s, when Pethrus saw the growing number of independent and incipient Pentecostal congregations in Sweden, he considered that "The Voice of the Bridegroom" was still insufficient to inform and inspire the rising movement. Maybe there was also already a slight crack in the collaboration between Pethrus and the other leaderssuch a split would become obvious at the end of the decade. Nevertheless, in 1916, Pethrus launched a journal of his own: "The Gospel Herald" (Evangelii Härold) - the main organ of the Pentecostal Movement until 1993. In 1921, the journal hired a new and brilliant editor, recently converted poet and writer Sven Lidman. In 1922, the success of "The Gospel Herald" drove "The Voice of the Bridegroom" out of the competition, and the latter had to be closed down. In 1945, under the leadership of Lidman, "The Gospel Herald" reached its peak with a circulation of 72,500 copies that, at the time, made it the largest journal of its kind in Sweden.

"The Gospel Herald" was aimed at a readership of Pentecostals throughout Sweden. In the 1940s, however, Pethrus and others saw the need for a means of reaching out to the greater Swedish society and influencing political debate. Consequently, he started the newspaper "The Day" in 1945, supported financially by Pentecostal industrialist Karl G. Ottosson - and opposed internally by Sven Lidman. The latter thought that a pure Pentecostal movement should not be soiled by mundane business. In spite of this, Pethrus and Ottosson were able to carry through their endeavor at a time when many newspapers were going out of business, and establish a Pentecostal mouthpiece in Swedish society.

In 1912, when Pethrus was still fairly unknown and the Filadelfia church was still a member of the Baptist Union of Sweden, ${ }^{9}$ he was encouraged by many of his members to publish a series of sermons as a book on Pentecostal eschatology called "Jesus Is Coming" (Jesus kommer). Interestingly, the Swedish title could be interpreted both as meaning "Jesus is returning" [now] and "Jesus is coming back soon." However, when he approached the Baptist publishing company, B-M.:s bokförlag, the editor asked, "Who would want to read a book of sermons, and by an unknown preacher?" Pethrus' manuscript was turned down-something that turned out to be a historical mistake on the part of that publisher; the book is still in print and has gone 
through 15 editions. Furthermore, Pethrus' efforts to publish the book led to the foundation of "The Filadelfia Publishing House" (Förlaget Filadelfia), for many years the major publisher of Christian books in Sweden, producing hundreds of titles, many of them in several editions. Publishing was discontinued in 1997 due to waning sales returns (Stävare 2007, 322).

In the 1940s and 1950s, healing was again on the public agenda. This aspect had been controversial even at the start of Pentecostalism in Sweden, but now the secular press focused upon it again. Newspapers like "The Daily News" (Dagens Nybeter) and "The Evening Paper" (Aftonbladet $)^{10}$ wrote story after story about the threat of Pentecostalism to conventional medicine and to scientific progress. In 1946, agitation against the Pentecostals led the state-owned "Sweden's Radio" (Sveriges Radio) to cancel a planned broadcast from the Stockholm Filadelfia Church because it had been claimed in a previous service that a person had been healed after intercession (Stävare 2007, 329). The experience of being banned outraged Pentecostals; Pethrus, the informal denominational leader, decided to challenge the Swedish radio monopoly and start an independent "pirate radio station." In 1949, Swedish Pentecostals were able to tune in to Radio Luxembourg to triumphantly listen to programs produced by their own denomination. But the quality of reception was poor and broadcasting was discontinued after a short time. In 1953, a second attempt was made from a "pirate ship" placed on international waters in the Baltic Sea. This attempt, however, was also short-lived. ${ }^{11}$ None of these efforts were explicitly illegal, because they could not be subjected to Swedish law, but they exasperated the Swedish authorities and threatened the idea of a state monopoly in broadcasting. ${ }^{12}$

In 1955, the endeavors to create a Swedish Pentecostal radio station came to fruition. With the foundation of the IBRA (the International Broadcasting Radio Association) earlier that year, the Pentecostal movement was able to secure a firm location ${ }^{13}$ for its broadcasts in Tangier, in today's Morocco, which at the time qualified as "international territory", and was therefore exempt from the strict broadcasting restrictions of Swedish law at the time. On July 29, 1955, Lewi Pethrus and Karl G. Ottosson flew into Tangier to inaugurate the new Swedish Pentecostal Radio Station. Thousands of expectant Pentecostals tuned in to the station. The station's aim of evangelizing Sweden via radio was quickly expanded to include missionary work in other countries. Thus, for a period of four and a half years, hundreds of programs, not only in Swedish, but in 23 different languages, were broadcast and provided Swedish Pentecostalism with a new medium for evangelization and supplementary missionary work (Stävare 2007, 329). When broadcasting 
from Tangier ceased in 1959, IBRA Radio continued to broadcast from a series of local radio stations in Asia, Africa, and Latin America. ${ }^{14}$

As stated above, the Swedish Radio monopoly was partially dismantled in April 1979, when the authorities allowed the creation of local radio stations, called "community radio" (närradio), which were in general run by non-profit organizations. The first one to make use of this opportunity in Sweden was the Pentecostal church of Jönköping, followed by their sister church in Linköping (Stävare 2007, 331). Soon, other Pentecostal congregations and many other different actors followed. This led IBRA to discontinue its production of programs for the Swedish listeners. ${ }^{15}$ By now, almost all Pentecostals had their own local radio station anyway. The year after, in 1980, the Swedish authorities also allowed the establishment of community television stations. The municipality of Huddinge, located just south of Stockholm, was the first to attempt this. Their key to success was cooperation with media students from the neighboring Pentecostal community college, Kaggeholm. Thus, Pentecostals once again played a part in a new media initiative in Sweden (Stävare 2007, 331).

In the 1980s, the Pentecostal Movement formed a partnership with the Canadian TV program 100 Huntley Street. This led to new ideas about television as a means for evangelizing in new regions, especially an increasingly secular Europe. During the annual Pentecostal conference outside Jönköping, Nyhemsveckan, in June 1983, this vision was presented at one of the sessions. The response was overwhelming; the following collection amounted to more than 1 million Swedish kronors (SEK, "Swedish crowns"), the largest offering to date in Swedish Pentecostal history. The Pentecostals had once again demonstrated their confidence in the use of modern mass media. A two-year television training course was launched at Kaggeholm in 1984, ${ }^{16}$ and TV production was initiated the same year by one of the Pentecostal companies called TV Inter. The sister churches in Denmark, Finland, and Norway joined in the enterprise. Only three years later, in 1986, the productions had reached such a professional level that the Swedish state television company (Sveriges Television) agreed to broadcast eight programs. ${ }^{17}$ The same year, TV Inter bought an old cinema hall in Stockholm and transformed it into a TV studio. In 1989, a series of $20 \mathrm{TV}$ shows for children were produced. In 1992, the Stockholm studio was considered too small and production was moved to more spacious facilities in Linköping. During the 1990s, TV Inter continued its struggles to establish itself as a significant player on the Swedish media scene. During its first five years, TV Inter was able to broadcast at least one 
program each weekend, in this period on the new commercial TV channels TV4 and Kanal 5. The programs transmitted included "Morning Air" (Morgonluft), "A Friend for Life" (En vän för livet), and the children's show Lenas Peplon (Wahlström 2007, 337).

In the 1970s, a series of programs featuring traditional revivalist songs, "The Whole Church Sings" (Hela kyrkan sjunger), led by Margit Borgström from the Pentecostal church of Umeå, were shown on Swedish television. The programs were widely discussed and Borgström became something of a celebrity in Sweden. Twenty years later, in 1997, mindful of the original program's success, TV Inter attempted to create a sequel: "Do You Remember the Song?" (Minns du saingen). This time inspiration was also taken from American singing duo Bill and Gloria Gaither's Homecoming programs in the United States. Under the direction of Anders Jaktlund and Urban Ringbäck, around 100 Christian artists, mostly Pentecostal, were brought to the studio in Linköping to participate in the program series. The sequel became even more popular than the original, and as a result Swedish television broadcast 25 episodes and number of reruns between 1998 and 2000 (Wahlström 2014a, 307; 2014b, 467).

After 1995, Pentecostal TV production faced increasing costs and around the year 2000, TV Inter concluded that the production of conventional TV programs for the Swedish market was no longer feasible. In 1999 the TV studio in Linköping was disposed of and its activities brought back to Stockholm. A series of people were dismissed and costs considerably reduced (Stävare 2007, 332). Today, attempts at televangelism seem to have vanished altogether. TV Inter now produces occasional Sunday morning services for Swedish state television. Otherwise, they concentrate on producing for-sometimes streaming on-the Internet. Programs on the Internet constitute a new mass media area, and are far less costly than conventional TV production. Apart from local initiatives by Pentecostal congregations, some successful websites have been launched, e.g. "Good News" (Goda Nyheter) with the subtitle: "The art of growing through the difficult issues of life." 18 The website provides instruction and counseling in areas like: "forgiveness," "unemployment," "recently divorced," "private economy," "guilt," "loneliness," and the like.

What has been accounted for so far pertains to the initiatives of the Swedish Pentecostal Movement. This denomination has been the leading actor, not only because of its size, but also because of its continuous interest in evangelization. Other Pentecostal movements, like the Örebro Mission and Maranata, have published books and journals but to a smaller extent. With the foundation of Word of Life in Uppsala, however, another significant actor 
appeared on the Christian media scene. ${ }^{19}$ From the start, books by Ulf Ekman and cassette tapes with recorded sermons were distributed on a large scale. In 1989, Word of Life also started a journal, "The Magazine" (Magazinet), which was continued until 2001 when it was replaced by "The World Today" (Världen $i$ dag). Starting in 1991, for a short time, television programs were produced for a European audience. In 1993, Word of Life acquired a license to broadcast radio programs in Uppsala, but the practice was soon discontinued because of the high expense (Coleman 2000, 168; Gerdmar 2014). In 1996, Word of Life acquired its first website and as of today all services are streamed and transmitted via the Internet.

In a brief recapitulation of Pentecostal media history, we may thus conclude that, within the Swedish Pentecostal movement, there has been an ever-present desire and openness to make use of the most recent mass media available. A desire to evangelize through these media has also been present ever since Pentecostalism started. The results of these campaigns have varied, but the desire to reach out has been palpable. ${ }^{20}$ In this more limited sense, Swedish Pentecostalism has attempted to make use of the television medium as "televangelism." However, if we define televangelism in the way many American researchers do, as connected to the creation of a "telechurch," televangelistic attempts by Swedish Pentecostals do not amount to true televangelism. In this context, I define a telechurch as an electronic church where the pastor acts from a studio with a few people who stand in as "members" while the real constituency, who make up the electronic church, are situated in front of their TV screens at home, communicating with their pastor only through donations and prayer requests (Hedges 2002,1118 ). This type of endeavor is a very different genre, and it has never been attempted on the Swedish scene because of the emphasis on congregationalism and collective leadership in Swedish congregations. A telechurch, as such, is based on the fame, skill, and charisma of a single preacher who creates a virtual church of his own. This kind of focus on one, central, charismatic figure thends to be frowned upon in traditional Swedish society in general, and in the congregationalist Pentecostal Movement in particular. ${ }^{21}$

\section{Televangelism: A General Background}

In the United States, televangelism began as early as the 1950s, in the infancy of television. And Pentecostals were there from the beginning. Oral Roberts' televised camp meetings from 1954 are considered to be the starting point. ${ }^{22}$ From 1960 onwards there was an "Oral Roberts special" every Sunday morning. This, in fact, became the basis for a new telechurch 
pastored by Roberts. As of 1969, Oral Roberts' ambitions were higher and the program was moved to "prime time." With the help of invited Hollywood stars, the number of viewers increased notably. Reverend Roberts made use of this opportunity to ask for money. He had recently founded Oral Roberts University in Tulsa, Oklahoma and needed more funds for its existence. When Roberts solicited money via this medium, the response was overwhelming. Roberts received more money that he could have dreamed of (Hedges 2002).

A colleague of Roberts, Southern Baptist Minister Pat Robertson, had started a similar enterprise in 1959, but he did it in a different way. He bought a TV station threatened by bankruptcy, and started broadcasting daily programs, transforming it into a Charismatic Christian TV channel. Robertson attracted more and more adherents, and at the height of his career, he seems to have had around 30 million "subscribers" that paid a "membership fee" and furthermore donated large sums of money. ${ }^{23}$ The result was a vast variety of programs including news, entertainment and, for a short time, also a soap opera. The surplus receipts covered the construction of the flamboyant Crystal Cathedral in California and, among other things, the unsuccessful Pat Robertson presidential campaign in 1988. Robertson reached many Americans, but not enough to reach the White House. ${ }^{24}$

The success of Oral Roberts and Pat Robertson attracted other preachers to televangelism, but the lure of money and massive followings also entailed temptations. From a present-day standpoint, it appears that televangelism in the United States declined notably during the 1990s. The flamboyant lifestyles and outright scandals connected to two of the big televangelists, Jim Bakker and Jimmy Swaggart, brought the whole business into disgrace. Both Pat Robertson's CBN (Christian Broadcasting Network) and Jim Bakker's PTL (Praise the Lord) network have now closed down. Today, there is only one major Charismatic TV station left in the United States, Trinity Broadcasting Network, or TBN. Daniel J. Hedges, Assistant Professor at Oral Roberts University in Tulsa, summarizes televangelism in the United States in the following way, emphasizing that Pentecostals and Charismatics have been the main protagonists of the business from the beginning, along with Oral Roberts:

No other segment of Christianity has employed television for evangelism and religious influence as successfully as charismatics and pentecostals [...] The overall result has been that television has taken both the best and the worst of charismatic and pentecostal Christianity into the home of virtually every family in America (Burgess and van der Mass 2002, 1118). 
Harvey Cox elaborates on mediatization in the following way, from a perspective especially important to the comprehension of televangelism:

$[\mathrm{T}]$ he power of the television medium transforms and magnifies the ordinary $[\ldots]$ Television is a modern technology that has a curious similarity to the magic of shamanism. The shrinking of distance, the larger-than-life presence, the compression of time, the sense of belonging suggested by the congregation's response, the appeal to emotion rather than logic-all integral to the topography of television. (Cox 1996, 278)

There are also other countries where televangelism has played a prominent role. Brazil might be the best example. One of the major Neo-Pentecostal denominations in the country, "The Universal Church of the Kingdom of God" (Igreja Universal do Reino de Deus) televised programs as one of its distinguishing characteristics from the beginning (Ruuth 1995, 195). In 1990, the leader of this denomination, Bishop Edir Macedo, ${ }^{25}$ bought two of the major TV channels in Brazil: TV Record in São Paulo and TV Rio in Rio de Janeiro. The cost was estimated at $\$ 45$ million (Burgess and van der Mass 2002; Ruuth 1995, 201).

In summarizing what he believes to have been the purpose of this bold venture, ecclesiologist Anders Ruuth states that the intention was:

[t]o reach as many people as possible with the message of the church. Radio and television are seen as the best instruments for reaching out. As we have seen, the message can be summarized as: Pare de sofrer. Existe uma solucao! ("Stop suffering! There is a solution!”). (Ruuth 1995, 207, author's translation)

It is interesting to note, however, that Bishop Macedo, who is all in favor of televangelism, seems to be against a particular form of telechurch. $\mathrm{He}$ states that:

I am against an electronic church of the type that we find in the United States, where the pastor is on the television screen and people are at home and attend the doorbell, if someone comes by, or the cat, if it is meowing. In my church we prefer direct contact with the people. (Ruuth 1995, 207, author's translation)

In this quotation, Macedo opposes the idea of a telechurch, referring to his vision of "direct contact" with the audience. One hypothesis to explain the success of American telechurches is the predominance of individualism 
in the United States. Maybe Macedo reckons that this is not as true of Brazil, even though the medium of TV is just as strong there. In Sweden, individualism has increased notably during the last decades. ${ }^{26}$ Has this opened up opportunities for a telechurch?

\section{The Purpose of Channel 10}

As was stated in the introduction, there is one particular case that seems to thwart the view of Sweden as a country that is infertile ground for telechurches: Channel 10 in Älmhult in southern Sweden. According to its founder, Börje Claesson, Channel 10 wants to practice televangelism, and has been doing so for a number of years. The first question that will be discussed here is whether, on the one hand, this endeavor reinforces the local churches leading to "a direct contact with the people" in accordance with Macedo's idea or if it, on the other hand, should be considered a new "telechurch" based on my definition of such a phenomenon stated above.

The birth of Channel 10 is intricately entwined with the aforementioned Claesson, a Pentecostal businessman from a traditional Pentecostal family. Claesson has several close relatives who are leading Pentecostal pastors within the SPM, a fact which has contributed to his securing a central position in the movement. He retired early from his business activities and initiated a local church in Älmhult. When he sold his company, a corporation that provided an electronic phonebook on the Internet, he made a gross profit and decided to invest the money in a Charismatic TV channel, something possible in Sweden in 2005 because of the restructuring of the media landscape described above.

In an interview in 2013 in "The Day," 27 Claesson was referred to as a "Smålandish Media Magnate" (småländsk mediamogul; Lundgren 2013, 11 , author's translation). His statement in the same interview does nothing to diminish that estimation: "I was a total failure, and nobody thought that I would start a TV channel. That goes against everything [that people think of me]. Nevertheless, I know that I will soon start a TV channel in Syria. I just know it" (Lundgren 2013, 11, author's translation). On Channel 10's website (2015) the ambition of the TV station is stated in the following way:

Channel 10 is Sweden's Christian TV channel. Here you will find a wide variety of programs, all with a clear Christian focus. Our telecasts include feature films, news, children's shows, education, debates, worship and intercession programs. One week each month we also broadcast our esteemed Café and Campaign Evenings. We offer a mix of music performances, interviews, 
and conversations directly from our studio in Älmhult. Channel 10 is a Christian channel, which is clearly evident in the programs we broadcast. We profess the Apostles' Creed, with Jesus clearly in focus. Channel 10 is not tied to any denomination but seeks as much breadth as possible. We telecast programs from the Oasis Movement within the Swedish church, to various free churches in Sweden. A few of our programs are broadcast in English, but most of them are either in Swedish or subtitled. Our goal is to broadcast as many of our programs as possible in Swedish. We broadcast Christian television around the clock, divided into three eight-hour blocks-one eight-hour block between 4 p.m. and midnight, and then a rerun of the programs until 4 o'clock p.m. the next day. ${ }^{28}$

The manifesto of Channel 10 demonstrates that it is an ecumenical, or at least a transdenominational collaborative, initiative that includes most of the Charismatic sector of Swedish Christianity, from the Oasis Movement within the Swedish Lutheran Church to, as we shall see below, NeoPentecostal enterprises like The Arch (Arken) and Word of Life. Studying the program schedule, we can also include the Swedish Pentecostal Movement, and Pentecostal preachers with their own ministry. Channel 10's own summary of its history reads:

Channel 10 began broadcasting in 2005. It has developed and has been growing steadily ever since. Since the inception, we have made major changes to the content of the programs, and we continually increase our viewer numbers. Today, apart from using the satellite disc (the Sirius Satellite), you can also order Channel 10 as an optional channel from the Freeserve and Telia selections. You can also follow Channel 10 via our Web TV..$^{29}$

In the interview in "The Day," Claesson professes that he has been inspired by the business strategy of the neighboring company IKEA:

The channel should be considered as a spiritual IKEA, which has a popular appeal. It started on a small scale, on the soil of Småland, but with time it became one of the most well-known trademarks in the world. From IKEA, I bring with me the idea of working as a team and that anyone can contribute with his or her gift. The company is a success today, but it was not like that in the beginning. (Lundgren 2013, 12, author's translation)

In this quotation it is hard to separate what Claesson alludes to as being IKEA's strategy from his own vision. But it becomes increasingly clear that his ambitions are not limited to a small church or a weekly television program. Claesson wants to reach out worldwide, just like IKEA. And just like IKEA's 
wide assortment, he claims, Channel 10 offers a great variety of programs. According to the Channel 10 website, these include: "TV shows from different parts of the world, from different communities and for different audiences: from the current talk shows and church services, news, children's shows and music programs." (Author's translation. Information found online at 'kanall0.se' April 12 2014.)

The program schedule of Channel 10 may be divided into six different kinds of programs: (a) news programs, (b) conventional church services, (c) teaching and counseling, (d) missionary activities, (e) testimonies, and (f) programs for children and youth. Each section is represented by at least two different programs: ambitions are high. Some of the programs, for example one of the news broadcasts, are produced in cooperation with a sister channel in Norway, "Channel 10 Norway" (Kanal 10 Norge).

The schedule referred to reflects the intention of Channel 10 to represent the breadth of Charismatic Christianity in Scandinavia. The news anchor is Tomas Ander, a Charismatic preacher of SPM origin. The leader of the program "Life with Jesus" is Linda Bergling, pastor of the Arch, a free Charismatic ministry in Stockholm, with historical ties to the Faith Movement. One of the missionary programs is led by Morgan Carlsson, who is the administrative secretary of Media Mission International (MMI), an organization that claims to be "the largest missionary organization in Europe, using mass media as a tool." One of the programs based on personal testimonies is called "From Darkness to Light," led by Hans and Eva Marklund, the pastor couple of the Faith Movement congregation in Alingsås. One of the children's programs, "Youngsters," is hosted by Lennart Henricsson from the Oasis Movement. Channel 10 has a standing element that is not accounted for in the program schedule: Börje Claesson asking for money. In between programs, and in the style of a commercial, Börje Claesson explains the vision of Channel 10 and asks the viewer to support his cause.

The enterprise is not limited to television, however. Channel 10 also provides encounters between viewers/sponsors and Charismatic celebrities, probably to encourage giving. In September 2014, for example, Christian business owners were invited to meet Sverre Larsson, the former director of "The Day Group" (Dagen-gruppen) of the Swedish Pentecostal Movement (see above). Another strategy for attracting attention is to let Charismatic profiles and celebrities write blogs on the Channel 10 website. In late 2014, former Word of Life leader Ruben Agnarsson asked the rhetorical question: "Do the missiles from the Palestinians really exist?" in one of the fairly frequent pro-Israel blogs featured on the site. 
Seen as a whole, the selection of programs and other activities seem to provide an extended version of what was once the contents of a traditional Pentecostal revival meeting. This contained Bible teaching, hymns, testimonies, and intercession-and youth activities as well as a Sunday school for children. During one of the hymns after the sermon, participants were regularly asked for an offering. Missionary reports were also often a part of the service. Seemingly, Channel 10 provides all the details that used to constitute this type of Pentecostal service: hymns, Bible teaching, testimonies, missionary reports, and pleas for support.

\section{Financing Channel 10}

In 2012, Channel 10 had 30 employees, around 100 volunteers (including Börje Claesson's staff), and, according to its own estimates, reached between 50,000 and 100,000 Swedish viewers per week. Potentially, however, 2 million Swedes could also watch its programs via their cable networks. These are impressive figures. But how does Claesson finance these extensive activities? According to Claesson himself, Channel 10 is partially financed by commercials, "but above all from the 9000 private donors and the 172 congregations that provide funds regularly" (Lundgren 2013, 12, author's translation). In 2012, Channel 10 actually collected some 20 million kronors and accounted for a profit of half a million kronors. When it comes to the identity of the supporters, Claesson is secretive. According to Lundgren:

Who they are, [Pastor Claesson] does not want to disclose, but for those who have watched Channel 10's programs, it soon becomes obvious that money is not an insignificant issue in this context. Blessings are promised to those who contribute - an attitude that the channel has been much criticized for. (Lundgren 2013, 12, author's translation)

The Channel 10 website (Kanal 10.se, 2014) provides us with a hint as to how the donations are acquired and administered. It echoes the petition by Börje Claesson in his frequent "commercials":

Channel 10 carries out great work to spread the gospel of Jesus. For the most part, the work is financed by voluntary donations. You can donate to Channel 10 in several different ways. Not only can you call or text a one-time gift using the numbers above. You can also make a donation through your account or credit card below. The most valuable [choice] for Channel 10 is of course if 
you want to become a monthly partner. You can also become one by clicking the button below "Become a partner." 1. Choose; 2. My gift; 3. My Details; 4. Check and complete. I want to: give a gift, become a partner.

Today, these partners obviously amount to more than 9000; on average, they provide more than 2000 kronors each per year (Lundgren 2013, author's translation). This is a considerable sum when it comes to donations from the general public. ${ }^{30}$

\section{Audiences of Channel 10}

Personally, I first came into contact with Channel 10 through my father, an old Pentecostal pastor, who was connected to the Comhem cable network and could watch the programs through that. He appreciated what he called "a tone of revival" (en väckelseton) that he recognized from his early years in the Pentecostal Movement. When I watched the programs together with my father, they often brought back memories from my childhood of revival campaigns and tent meetings. Some of the participants were even the same, for example Målle Lindberg, who calls himself "a gypsy preacher" and who made the front page of several evening papers with his spectacular performances in the 1960s. At that time, he was related to the short-lived, "wild" Pentecostal movement of Maranata (Dahlgren 1982, 139-42).

It is obvious that not only my father, but many elderly Pentecostals appreciate the Channel 10 programs. According to an article in "The Day," 75 percent of all incoming telephone calls come from elderly people. Journalist Lundgren states that: "There is no doubt about the fact that the channel means a lot to many in this age group. A collection of incoming letters leaves no doubt and [they] express pure gratitude" (2013, 13, author's translation). In one of my interviews, a female member of the Pentecostal Movement stated the following about Channel 10:

I watched a Bible study on marriage that was one of the best I ever heard. I saw a fine report about poverty in South America that illuminated the problems but also the efforts that have been made, in a very informative way. I have seen touching interviews that expressed needs for intercession, but also peoples' testimonies about how they have been helped through Channel 10. ${ }^{31}$

This testimony, as well as many others, accounts for the appreciation for Channel 10 that is shown by viewers of a Pentecostal/Charismatic background. 


\section{The Effects of Televangelism}

The bold vision of Börje Claesson, however, is televangelism. He claims that through his TV channel, "God's fire will spread all over Scandinavia, with hundreds of thousands saved as a goal." Furthermore, he states that: "This is revival. It is our calling to transmit the message to the Swedes, to be a tool for revival in Sweden and confer hope to the congregations" (Lundgren 2013, author's translation). This quotation clearly demonstrates Claesson's own vision: Channel 10's televangelism will reach out to secularized Scandinavians, bring them to salvation, and thus transform the whole region. Scandinavia will be ignited by and burn with Pentecostal fire. In the process, the local Pentecostal or Charismatic congregations will be filled with hope.

The results from earlier studies of televangelism in the United States do not point in that direction, however. Daniel J. Hedges concludes that "the impact on society at large appears to be relatively small; fundraising rhetoric notwithstanding, religious television appears to reach mostly the converted and have little evangelistic impact" (2002, 1120). Experience from other televised attempts in Sweden would suggest the same. Above, we have described initiatives like "Do You Remember the Song?" produced by the Pentecostal missionary organization TV Inter, but broadcast on Swedish state television. These programs were viewed by a great many people and were much talked about. But the effect can probably be labeled "nostalgia," rather than "conversion." Innumerable church services all over Sweden were later called "Do You Remember the Song?" but there were extremely few new converts to Pentecostalism as a result, if any. ${ }^{32}$ The intention may have been televangelism, but the effect was most probably nostalgia and the nostalgia produced did not result in conversion.

As stated above, SPM's TV Inter has concluded that producing this type of program is too expensive considering the meager results. Thus, they have almost abandoned televangelism in Sweden. Börje Claesson and Channel 10, however, think otherwise. The format and the vision of this channel differ considerably from any other endeavor so far in Swedish history. With the "tone of revival" from bygone days, music accompanied by accordions and guitars, and emotional sermons, Claesson and his revivalist friends intend to "save" not only Sweden, but all of Scandinavia. And in one respect, they have succeeded where others, like SPM and Word of Life have failed. They have been able to finance a Pentecostal Charismatic TV channel for years. 
As noted above, Claesson claims that: "This is revival!" There are a number of issues that pull that claim into question, however. The people that travel to Claesson's "City Church" in Älmhult are already believers seeking healing, consolation, or maybe just nostalgia. As we have seen, the majority of those making phone calls and donating money are elderly people, most of whom are obviously believers. When it comes to the programs broadcast by Channel 10, we may also call into question the character of these programs. The style is often old-fashioned compared to today's Pentecostal and Neo-Pentecostal church services. The songs are old and popular Pietist hymns. But what is most surprising is the type of speech employed on these programs. The language used is full of Bible references and Pietist expressions, fully comprehensible to an old believer, but probably incomprehensible to the nonbeliever that Claesson wants to reach. Lundgren states that: "The question is-Does the channel reach the people it opts for? Is the classical revivalist language understood by secularized Swedes that, in a fragmented existence, never find enough time as it is?" $(2013,13$, author's translation $) .{ }^{33}$

\section{Is Nostalgia the Key to Channel 10's Success?}

According to the arguments presented above, Channel 10 is not likely to become the ideal of televangelism that Claesson wants it to be. It does not reach out to "Scandinavia," not even to secularized Sweden. But why has it become a success, at least if we consider it from the perspective of "survival" in a tough media business? Channel 10 has obviously stayed alive for a long time-longer than could have been expected, considering the size of Claesson's initial investment of funds. To explain this, we must instead look at the situation of Pentecostal believers in Sweden today to find the answer. As hinted at above, classical Pentecostal churches have undergone a dramatic transformation in just one or two decades. The spirituality of the 1940s and 1950s, the time when today's elderly people were young, is all gone. There are no more prophetic messages, speaking in tongues, prayer nights, revivalist hymns, no more string instrument orchestras or church organs, not even any hymn books. All these classical expressions of revivalism are more or less gone (cf. Moberg 2013, 106-107). Many oldtime believers have a hard time recognizing their old churches, even more so in taking a liking to them. They are faithful and do not leave the church officially, but they do not feel at home and they are more and more often becoming absent friends. 
The rapid alteration of religious expressions such as classical Pentecostal church services can be attributed to several factors. First, individualism has spread rapidly in Sweden during the last few decades. People do not bother as much about what others think. The predominantly rural and collectivist culture of Sweden has been replaced by an urban and individualist one. Furthermore, people increasingly vote with their feet. Whereas old-time Pentecostals were most faithful to their congregations, Jessica Moberg (2013) has shown that today's members are mobile and choose a congregation according to what they consider the best for that moment. This has led to a nervous adaptation to new circumstances in many churches. This whole rapid transformation of churches and church culture opens up a new field to actors like Claesson, and media enterprises like Channel 10. Alienated Pentecostals are looking for a new home-but wish to do so without having to do what was once considered almost a sin, that is, to abandon their congregation. This is where Claesson's TV channel comes in. In the programs from Channel 10, they recognize "a tone of revival" and more. They feel at home again.

At the same time, another process is going on in Swedish society: mediatization, i.e., the influence of mass media on Swedish culture in a broad sense: "In all fields of culture, the presence of the media changes the rules of aesthetic creation, dissemination and the use of sound, images, and texts. To a high degree, mediatization affects reading and listening, education and the book industry, theater and the music, film and visual culture in both fine arts and popular culture" (Fornäs 2011, 5). It goes without saying that the author also should have included church services. In line with the transformation of Swedish TV media from sober information services to "commercial populism" in the 1980s (Furhammar 2006), or the more recent trend of "digital storytelling," Channel 10 has produced a popular form of revival, maybe not of the heart, but definitely of the culture of bygone days in Pentecostalism. And, just like in the old days, people are happy to open their wallets and donate money to something that is to their liking-and especially to a TV channel that claims that it is going to bring old time revival to Scandinavia!

Through his work on identity, Paul Ricoeur (1992) has taught us that we are dependent on narratives to create and maintain a personal identity. By telling and retelling stories of our lives, we integrate a reconstructed past and an imagined future, and we mediate discrepancies to produce a more coherent version of continuity. In the same way, we opt to provide life with some type of purpose. Stuart Hall speaks of the "production of 
identity" and claims that this process is "not an identity grounded in [Foucaultian] archaeology, but in the re-telling of the past" $(1990,224)$. Dan McAdams and Kate McLean further suggest that "a narrative identity builds slowly over time as people tell stories about their experiences to and with others. Over developmental time, selves create stories, which in turn create selves" $(2013,233)$. Erik Erikson emphasized the importance of continuity in the notion of personal identity: "The key problem of identity, then, is (as the term connotes) the capacity of the ego to sustain sameness and continuity in the face of changing fate [...] Identity connotes the resiliency of maintaining essential patterns in the process of change" (Erikson 1964, 95-96). In a situation where a positive interpretation of the present is difficult to attain or create, an individual often turns to the past, something we call "nostalgia." Up until recently, nostalgia was considered a deficient character trait. Recent research, however, has shown that nostalgia is a common and transcultural phenomenon that "bolsters social bonds, increases positive self-regard, and generates positive affect" (Routledge et al. 2006, 975).

In the case of elderly people in the classical Pentecostal Movement, the construction of an identity and purpose in life becomes increasingly difficult in the radically transformed environment of the local Pentecostal church. The perception of continuity is suddenly disrupted. Thus they revert to nostalgia, returning to the past. This explains the success of programs like "Do You Remember the Song?" that feature old-time revival songs as well as mediatized versions of old-school Pentecostal services. In these programs, viewers are helped to return to the past. The programs from Channel 10 are not just passive nostalgia, however. Through the repeated pleas for donations from Börje Claesson, followed by nostalgic satisfaction in return, as well as the chance to submit prayer requests, etc., the interchange results in a mutual interdependence. The talk around coffee tables around Sweden — or visits to the City Church in Älmhult—also provide individuals with chances to retell the stories of their lives, thus renewing their perceptions of their personal identities and creating new meanings and new purposes in life for them.

Indulging in nostalgia is a convenient way to feel better and open up to others. It opens the heart and boosts generosity, which accounts for the fact that it has been possible for Claesson to generate the large sums that he needs. This has made it possible for him and his collaborators to create what I consider to be Sweden's first telechurch. Around Sweden, what is broadcast from Ängelholm is now the talk of the coffee tables of elderly Pentecostals and other Charismatic believers. And day after day, former 
churchgoers now sit in front of the screen, awaiting new inspiration, reinforced by nostalgia. While still remaining members of a local church, elderly and disappointed members of Pentecostal and Charismatic origin can increasingly identify with a media version of a church-a telechurch. What Bishop Macedo did not want, is exactly what Pastor Claesson has achieved-in a time that no one thought was "right" for religious television. According to this interpretation, Channel 10 is most certainly the answer-but, in the eyes of Börje Claesson, and many of his sponsors, probably to the wrong question. The channel may not have met the supposed needs of nonbelievers, but it has definitely brought new meaning to the lives of the older believers who feel alienated in their own churches.

\section{Notes}

1. The term televangelism is usually considered to be an (American) abbreviation of "evangelization via television." However, the term also indicates a translocative capacity of broadcasting activities that take place elsewhere, thus making them available for "take-away"-for remote consumption or participation.

2. I use "Pentecostal" as an encompassing term for the type of spirituality that originated among African Americans in the United States in the early twentieth century, regardless of its current location. To single out this type of Pentecostalism, I sometimes use the term "Classic Pentecostalism." This stands in contrast to the type of Pentecostalism that surged towards the end of the twentieth century, which is more related to "health and wealth" theology. I use the term "Neo-Pentecostal" for the latter. To define Pentecostalized movements within other types of churches, like the Swedish Lutheran Church, I use the term "Charismatic." The latter may also be used as an encompassing term to define spirituality common to Classic Pentecostalism, Neo-Pentecostalism, and the Charismatic Movement (for a more detailed discussion, see Alvarsson 2007b).

3. The material, consisting of several interviews, a visit to the location of TV production in Älmhult, and an analysis of viewer statistics, was presented as a spread in "The Day" (Dagen) Sept. 6, 2013.

4. For an overview of the different Pentecostal movements in Scandinavia, see Alvarsson (2011) and for the Swedish Pentecostal Movement in particular, see Alvarsson (2007a).

5. In this article I use "The Swedish Pentecostal Movement" and the abbreviation SPM for the main Pentecostal movement in Sweden. From 2001 this movement was more officially organized and called Riksföreningen Pingst Fria församlingar i samverkan; in English "The Pentecostal Alliance of Independent Churches" or "PAIC." As most of the historical events in 
this article took place before 2001, however, I will keep the abbreviation "SPM" throughout the text.

6. Initially, the company was organized as a foundation, founded by the Swedish government as a Public Service company, but corporately owned by interested parties, like the press, the news agency "TT," and radio companies. It was supposed to be independent of the government or any economic interests, but it was still closely identified with the Swedish state. After 1979, when Sveriges Television (Swedish Television) was founded as a separate foundation, the board has been constituted by representatives of all the political parties in the Swedish Parliament, with a president who is politically independent.

7. For more detailed information, see Alvarsson (2014a).

8. Närke is the name of the province of the city of Örebro.

9. Most Pentecostal congregations were founded as independent entities resulting from the revival. However, some of them, like the Filadelfia Church in Stockholm, were originally Baptist congregations, even though there was also an influx from Methodists and later the Swedish Covenant Church. The Filadelfia Church in Stockholm was explicitly expelled from the Baptist Union in 1913, only one year after the publication of "Jesus is Coming," while other congregations left the Union in protest or because of differences in spirituality.

10. See e.g. Dagens Nyheter, Feb. 1, 1950, Aftonbladet, Feb. 2, 1950, and Expressen, Feb. 17, 1950. cf. the conditions in the 1920s in Stävare (2010, 70-74).

11. This attempt was followed by the founding of Denmark's most successful pirate radio station, the commercial and secular Radio Mercur in 1958, and its Swedish imitators, Radio Syd outside southern Sweden the same year, and Radio Nord, outside Stockholm in 1961. All of these attempts naturally increased the pressure on Swedish authorities to open up the country to more commercial media.

12. Lewi Pethrus also tried to realize his vision through legal methods by negotiating with the Minister of Communication on several occasions, but without result (Stävare 2007, 329).

13. With the foundation of IBRA, the Pentecostal Movement was able to escape the limiting currency regulations in force in Sweden at the time, because no Swedish citizen could be prevented from being a member of a foreign association or send his or her membership fee to that association (Djurfeldt 2007, 203).

14. In 1971, Radio Trans Europa in Lisbon became a new center for IBRA activities. In 1985, IBRA broadcast in 53 languages and reached 150 peoples in more than 100 countries. Seventeen million Swedish kronors per year were invested in IBRA at the time (Stävare 2007, 330). 
15. IBRA Radio discontinued broadcasting in Swedish in March 1980 (Björk 2007, 291).

16. The Kaggeholm community college already had a mass media education program which was responsible for the community television project in Huddinge. On the basis of that experience, and inspired by the Canadian 100 Huntley Street (and with two presenters from that TV station), formal television education began in 1984 (Björk 2007, 292). This channel has produced many of the present technicians, anchormen, sound technicians, and cameramen working for Swedish Television (Kanal 1 and TV2) as well as TV4.

17. At this stage, to cut costs, Swedish Television started buying programs from freelance companies who were also based in Sweden. However, the quality requirements were high, and it was a surprise to some skeptics that the SPM passed the audition. Four of the programs mentioned in the text were broadcast during 1986 and the rest during 1987 (Björk 2007, 292).

18. In Swedish: "Konsten att växa genom livets svåra frågor." (Author's translation). The address is http://www.godanyheter.nu/.

19. In his study of Word of Life, Simon Coleman has highlighted the interesting fact that mass media were also "incorporated into members' spiritual lives and practices," i.e. they were used as complements to regular church services (Coleman 2000, 168).

20. One evangelization campaign, launched by German-born international evangelist Reinhard Bonnke in the 1980s, attempted to reach all Swedish households with Bonnke's pamphlet "From Minus to Plus" (Från minus till plus) which was generally a magnificent failure. No new converts were seen. In the aftermath, many Pentecostals ironically reversed the title of the campaign.

21. For the Swedish mentality, see Daun (1989). For Pentecostal views on congregations, see Josefsson (2005, 97-108).

22. Pentecostal evangelist Kathryn Kuhlman also contributed to a number of TV programs with features from her healing campaigns in the 1950s and the 1960s, broadcast on CBS (Columbia Broadcasting System), at the time one of the major TV companies in the United States.

23. In the United States, religious groups' collections are exempt from taxation.

24. Scandals and conflicts have since struck the Robertson family. The TV channel decreased in importance and no one was ready to take over from the aging Robertson. The Crystal Cathedral had to be disposed of. Today, it is owned by the Catholic Church.

25. In many Pentecostal denominations, especially in African American ones, the first pastor takes the title "Bishop" in accordance with 1 Tim. 3:1: "the office of a bishop" (i.e. not as part of an idea of succession). This is also the case in IURD and some other Latin American churches. 
26. See the World Values Survey (2015), according to which Sweden is now considered the most individualistic country in the world.

27. As stated above, Dagen was founded in 1945 by Lewi Pethrus and was for a long time associated with the SPM. Today, however, a consortium of Christian actors, ranging from SPM to a Norwegian Lutheran organization, jointly finance and supervise the production of Dagen.

28. Author's translation of the statement found online at 'kanall0.se' April $12,2014$.

29. Author's translation of the information found online at 'kanall0.se' April $12,2014$.

30. According to Dagens Nybeter of Aug. 12, 2014, official Swedish statistics state that the average Swede donates 600 kronors per year to nonprofit organizations in general. Donors to Channel 10 probably also give money to other causes, e.g., their own local churches, which indicates that this number is indeed exceptional.

31. Interview with Pentecostal woman, 65-70 years of age, April 14, 2015.

32. The response to the show, in particular the proliferation of church services called "Minns du sången", actually caused Swedish Television to discontinue the broadcast of the series (Dagen, Nov. 6, 2001).

33. Lundgren's observations coincide exactly with my own, gathered from watching many programs produced by Channel 10 .

\section{REFERENCES}

Alvarsson, Jan-Åke. 2007a. Pingstväckelsens etablering i Sverige: Från Azusa Street till Skövde på sju månader. In Pingströrelsen: Händelser och utveckling under 1900-talet, ed. Jan-Åke Alvarsson and Claes Waern, vol. 1, 10-45. Örebro: Libris.

- 2007b. Pentekostal, evangelikal och karismatisk: Definitioner av några viktiga begrepp. In Pingströrelsen: Verksambeter och särdrag under 1900-talet, ed. Jan-Åke Alvarsson and Claes Waern, vol. 2, 40-49. Örebro: Libris.

- 2011. The Development of Pentecostalism in Scandinavian Countries. In European Pentecostalism, ed. William K. Kay and Anne E. Dyer, 19-39. Leiden/ Boston/Tokyo: Brill.

—. 2014a. Om Pingströrelsen... Essäer, översikter och analyser. Skellefteå: Bokförlaget Artos.

Björk, Annica. 2007. Pingströrelsen blev största frikyrkan: Fler än 25.000 döptes under en tioårsperiod. In Pingströrelsen: Händelser och utveckling under 1900talet, ed. Jan-Åke Alvarsson and Claes Waern, vol. 1, 289-315. Örebro: Libris. Burgess, Stanley M., and Eduard van der Mass, eds. 2002. International Dictionary of Pentecostal and Charismatic Movements. Grand Rapids: Zondervan.

Coleman, Simon. 2000. The Globalisation of Charismatic Christianity: Spreading the Gospel of Prosperity. Cambridge: Cambridge University Press. 
Cox, Harvey. 1996 [1994]. Fire from Heaven: The Rise of Pentecostal Spirituality and the Reshaping of Religion in the Twenty-First Century. Reading: AddisonWesley Publishing Company.

Dahlgren, Curt. 1982. Maranata: En sociologisk studie av en sektrörelses uppkomst och utveckling. PhD dissertation, University of Lund.

Daun, Åke. 1989. Swedish Mentality. University Park: The Pennsylvania State University Press.

Djurfeldt, Olof. 2007. Missionsintresset växte i förnyelseväckelsen: Allvarliga profetior i krigets skugga. In Pingströrelsen: Händelser och utveckling under 1900talet, ed. Jan-Åke Alvarsson and Claes Waern, vol. 1, 177-219. Örebro: Libris.

Erikson, Erik. 1964. Insight and Responsibility. New York: Harper \& Row.

Fornäs, Johan. 2011. Medialisering: Introduktion. In Medialisering av kultur, politik, vardag och forskning: Shutrapport frain Riksbankens Jubileumsfonds forskarsymposium i Stockholm 18-19 augusti 2011, ed. Johan Fornäs and Anne Kaun, 5-13. Huddinge, Mediestudier vid Södertörns högskola.

Furhammar, Leif. 2006. Sex, såpor och svenska krusbär: Television $i$ konkurrens. Stockholm: Ekerlid.

Gerdmar, Anders. 2014. Livets Ord. In Svenskt Frikyrkolexikon, ed. Jan-Åke Alvarsson, 274-277. Stockholm: Bokförlaget Atlantis.

Hall, Stuart. 1990. Cultural Identity and Diaspora. In Identity: Community, Culture, Difference, ed. Jonathan Rutherford, 222-237. London: Lawrence \& Wishart.

Hedges, Daniel J. 2002. Television. In International Dictionary of Pentecostal and Charismatic Movements, ed. Stanley M. Burgess and Eduard van der Mass, 1118-1120. Grand Rapids: Zondervan.

Josefsson, Ulrik. 2005. Liv och över nog: Den tidiga pingströrelsens spiritualitet. $\mathrm{PhD}$ dissertation, University of Lund.

Kanal 10. http://www.kanall0.se. Accessed 6 Mar 2016

Lundgren, Joakim. 2013. Kanal 10 - första tv-kyrkan i Sverige. Dagen, September 6.

McAdams, Dan P., and Kate C. McLean. 2013. Narrative Identity. Current Directions in Psychological Science 22: 233-238.

Moberg, Jessica. 2013. Piety, Intimacy and Mobility: A Case Study of Charismatic Christianity in Present-Day Stockholm. PhD dissertation, Södertörn University.

Ricoeur, Paul. 1992 (1990). Oneself as Another (Soi-même comme un autre). Chicago: University of Chicago Press.

. 2005. The Course of Recognition. Harvard: Harvard University Press.

Routledge, Clay. 2015. Nostalgia: A Psychological Resource, Essays in Social Psychology. Abingdon/New York: Routledge.

Routledge, Clay, Tim Wildschut, Constantine Sedikides, and Jamie Arndt. 2006. Nostalgia: Content, Triggers, Functions. Journal of Personality and Social Psychology 91: 975-993.

Routledge, Clay, J. Juhl, A. Abeyta, and C. Roylance. 2014. Using the Past to Promote a Peaceful Future: Nostalgia Proneness Mitigates Existential Threat Induced Nationalistic Self-Sacrifice. Social Psychology 45: 339-346. 
Ruuth, Anders. 1995. Igreja Universal do Reino de Deus: Gudsrikets universella kyrka: en brasiliansk kyrkobildning. Uppsala/Stockholm: Almqvist \& Wiksell International.

Stävare, Nils-Eije. 2007. En mediemedveten väckelserörelse: Dagen flaggskepp i bred massmediesatsning. In Pingströrelsen: Verksambeter och särdrag under 1900talet, ed. Jan-Åke Alvarsson and Claes Waern, vol. 2, 319-359. Örebro: Libris.

- 2010. Pingstvännerna - värstingkristna för hundra år sedan. In Värstingkristna $i$ drevet, ed. Kerstin Elworth et al., 51-84. Artos: Skellefteå.

Wahlström, Magnus. 2007. Omprövning av tidigare principer: Kvinnlig ledarskap exempel på rörelsens nyorientering. In Pingströrelsen: Händelser och utveckling under 1900-talet, ed. Jan-Åke Alvarsson and Claes Waern, vol. 1, 317-353. Örebro: Libris.

- 2014a. Minns du sången. In Svenskt Frikyrkolexikon, ed. Jan-Åke Alvarsson, 307. Stockholm: Bokförlaget Atlantis.

- 2014b. TV-Inter. In Svenskt Frikyrkolexikon, ed. Jan-Åke Alvarsson, 467. Stockholm: Bokförlaget Atlantis.

World Values Survey. 2015. http://www.worldvaluessurvey.org/WVSContents. jsp?CMSID=Findings. Accessed 23 Dec 2015.

\section{Ethnographic Material}

Interview with Pentecostal woman, 65-70 years of age, April 14, 2015.

Open Access This chapter is distributed under the terms of the Creative Commons Attribution 4.0 International License (http://creativecommons.org/licenses/ by $/ 4.0 /$ ), which permits use, duplication, adaptation, distribution and reproduction in any medium or format, as long as you give appropriate credit to the original author(s) and the source, provide a link to the Creative Commons license and indicate if changes were made.

The images or other third party material in this chapter are included in the chapter's Creative Commons license, unless indicated otherwise in a credit line to the material. If material is not included in the chapter's Creative Commons license and your intended use is not permitted by statutory regulation or exceeds the permitted use, you will need to obtain permission directly from the copyright holder.

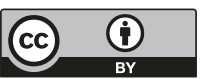

